\title{
The position of relationship based practice in youth justice
}

Purpose: This paper considers the position of relationship-based practice in youth justice by looking at how 'effective programmes' seem to have been given heightened importance over 'effective' young person-worker relationships.

Design: By critically reviewing the literature on the topic, the paper promotes debate on the position of relationship based practice in youth justice.

Findings: It is argued that the young person-worker relationship is very important. A genuine and empathetic relationship can reduce the chances of re-offending and improve the child's personal, social and emotional development. By being respectful and listening attentively to children's 'life stories', barriers can be overcome, potentially resulting in lifestyle, social and behavioural change. However, although there is evidence that developing a trusting relationship is 'effective' and that it is a key component of effective practice, what is less clear is how to practically secure the engagement of a child.

Originality: In comparison to the emphasis on effective programme intervention, there has been less research done on the 'characteristics' of effective staff practice in youth justice.

Key words: Relationships, youth justice, young offenders, youth crime

\section{Introduction}

It is the intention of the paper to consider the 'position of relationship-based practice' (Burnett and McNeill, 2005) in youth justice, in particular looking at how 'effective programmes' seem to have been given heightened importance over 'effective relationships' (Batchelor and McNeill, 2005). Indeed, in comparison to the emphasis on effective programme intervention, there has been less research done on the 'characteristics of effective staff practice' (NYA, 2011:6).

\section{The 'What Works' debate}

In 1974 Robert Martinson argued that: 'even if we can't 'treat' offenders so as to make them do better, a great many of the programmes designed to rehabilitate them at least did not make them do worse' (p.48). He went on to argue that there was 'no clear pattern to indicate the efficacy of any particular method of treatment' (Martinson, 1974:49). This was widely interpreted as 'nothing works' in reducing offending. However, he later went on to 'withdraw' this conclusion: 'I have often said that treatment added to the networks of criminal justice is 'impotent', and I withdraw this characterisation' (Martinson, 1979:254).

However in response to the 'Nothing Works' pessimism, meta-analytical studies have discovered the 'characteristics of interventions with offenders that [are] associated with improved prospects of a reduction in subsequent offending' (Smith, 
2006:368). Indeed, it was found that the intensity and duration of the intervention should be matched to the risk level (low, medium, high), and the content of the intervention should be informed by the 'criminogenic needs' of the offender (Mclvor, 1990).

However, despite 'optimism' that the principles of effective practice have been identified, they have been uncritically accepted (Mair, 1997). The principles (namely risk classification, criminogenic need, responsivity, community base, treatment modality, and programme integrity) are promoted as being proven definitively to be 'What Works' at reducing re-offending (Robinson and Crow, 2009). However, although this 'hard evidence' offers a set of 'best buys' or 'helping strategies', it somewhat disregards practitioner experiences - classifying reflection as a form of self-indulgent navel-gazing. However, despite these challenges, evidence based practice is promoted as offering a form of certainty and tidiness to the unpredictable reality of youth offending.

'What Works?' is a question that demands exploration: it should not be deemed a 'statement or formula to be applied in any routinised way to individual children and young people' (Whyte, 2004:3). Having said that, the 'what works' literature supports the idea that approaches should be multi-modal, that is holistic in nature to meet the needs of the offender, comprising structured counselling sessions, and positive reinforcement, alongside cognitive behavioural therapy (thinking skills) (McGuire and Priestly, 1995). However, the 'What Works' movement has been criticised for 'wasting the creativity of youth justice professionals as it places at risk much of the genuinely good practice undertaken by them' (Bateman and Pitts: 2005:258). Indeed, practice, at times, is defensive, as practitioners act as 'technicians, encouraged to do as they are told, rather than professionals who might think independently, question orthodoxy and produce creative and inspired work' (Bhui, 2001:638).

The movement has been accused of somewhat ignoring the significance of 'effective' relationships (McNeill and Batchelor, 2002). More specifically, despite the emphasis on 'programme integrity' - concerned with ensuring that the content and methods are compatible with the aims and objectives of the activity - for positive outcomes to result, it 'may actually depend on the skills, knowledge and experience of practitioners in the exercise of autonomous judgement' (Prior and Mason, 2010:220).

\section{The young person - worker relationship}

Developing a trusting relationship with a child remains crucial (Trevithick, 2012). A genuine and empathetic relationship can reduce the chances of re-offending and improve the child's personal, social and emotional development (NYA, 2011). Indeed, by being respectful and listening attentively to children's 'life stories', barriers can be overcome, potentially resulting in lifestyle, social and behavioural change (Beyond Youth Custody, 2014; NYA, 2011). However, although there is evidence 
that developing a trusting relationship is 'effective' and that it is a key component of effective practice (Baker, et al., 2011) what is less clear is how to practically secure the engagement of a child (Prior and Mason, 2010).

Drawing on the work of Burnett (2004), Prior and Mason (2010:217) argue that the youth offending field lacks a satisfactory evidence based on the role of interpersonal relationships in engaging young people in interventions designed to enable desistance from crime'. However, it is argued that passive involvement, where the child is somewhat disinterested in the activities on offer, results in the programme (regardless of the design) not delivering the desired effect (Mason and Prior, 2008). Indeed, the success of the intervention 'hinges significantly upon the interpersonal behaviour of the staff they encounter' (Koprowska, 2010:34).

By understanding the perspective of the young person the professional is not 'condoning' the behaviour. Rather by being 'empathic' to the circumstances, the professional greatly increases the chances of a 'good relationship' developing and any proposed intervention being a success. Furthermore, 'being directive and persuasive is more likely to be effective where we have a good relationship with the individual in question' (Trevithick, 2005:202).

The 'What Works' movement has been accused of making practitioners feel devalued: the ability to deliver individualised interventions is constrained by performance indicators and risk management processes and procedures. Despite this, professionals continue to emphasise the importance of a 'trusting relationship' (Burnett and McNeill, 2005). Indeed,

...These 'core conditions of effectiveness' include: empathy and genuineness; the establishment of a working alliance; and the adoption of person-centred, collaborative and 'client-driven' approaches (McNeill, 2006a:130)

Although the completion of a good assessment - where risks and needs are identified - is at the heart of effective practice (McGuire, et al., 2002), equally important is the development of a 'quality relationship' and belief that young people can be rehabilitated (Prior and Mason, 2010).

It is important to acknowledge that, during the 'what works' movement, practitioners were increasingly enjoined to focus on programmes with relationships taking on a less prominent role. However, practitioners did continue to recognise its importance, perhaps due to the interactive nature of the work.

\section{The road to desistance}

The political rhetoric is that the youth justice system will reduce, if not stop, offending amongst young people. The reality is that it will systematically fail in this regard if it does not take into account the views of young people themselves about what helps them in the process of desistance. 
(Barry, 2009:92)

Barry (2009: 90), in a study exploring young people's attitudes to criminal justice interventions, noted that 'better intervention, for many young people in the youth justice system means non-coercive and negotiated engagement with workers within a caring rather than controlling environment'.

One could argue that 'what young offenders feel may help them stop offending runs counter to the policy rhetoric ... about punishing or correcting (Barry, 2009:78).

Rather, the experience of young people 'is of social and structural barriers to change and participation in society' (Barry, 2009:79). One approach that has given credence to the perspective of the child is that of desistance theory. Indeed, within this paradigm young people are deemed to be 'active participants' rather than 'objects of 'treatment' or 'intervention', characterised by needs and deficits and presenting risks' (Raynor, 2004:221). The instilling of 'hope' and 'self-confidence' is deemed to be important here. Rather than the intervention or level of support offered being driven solely by the 'criminogenic' needs of the offender, it is argued that, there should be equal importance given to the positive aspects of a child's life, drawing on strengths based approaches and informed by the literature on resilience. Most importantly, it involves 'fostering a sense that the young person can change, and reinforcing an awareness of what he or she has to offer' (Nacro, 2007:5).

Desistence literature and research provide a 'welcome bulwark against the 'risk' and 'what works' agenda' (Nugent and Barnes, 2013:21) by shifting the focus away from the child's deficits and onto their strengths. The development of the child's selfesteem is prioritised and so too is the role of the social context and the part it plays in offending.

The counterproductive (and even 'destructive') process of labelling children 'offenders' is highlighted within this paradigm. Labelling children in this way presents significant barriers to change as it instils a sense of failure and contributes to the child embracing the concept of 'offender'. It is argued that the process of desistance can be enhanced by promoting positivity (King, 2013) and this is realised by helping them to identify what is 'meaningful' in their life. The notion of crime is problematised and re-defined as a social justice issue - understanding that children experience a range of inequalities that need to be properly addressed.

Rex (1999) echoes earlier points regarding the importance of positive working relationships. Here, the point is made that if the supervising worker has a genuine interest in the person's life this can help to develop a respectful and trusting relationship and 'promote desistance' from crime. Perhaps it is more difficult, though, to develop such a relationship with offenders who have been categorised as high risk, as the lives of such people can be more problematic. However in order to promote desistance with these individuals, expectations should be realistic (Weaver and McNeill, 2007) where a 'one size fits all' mentality is avoided (Weaver and 
McNeill, 2010). As part of the supervision process practitioners should be aware that relationships are important, not just between the worker and the child, but also between the young offender and people who are important to them in their life (Burnett and McNeill, 2005).

Other matters are important too in the supervision process. Rather than practice being solely driven by the risk-need framework, and done 'to the child' rather than 'with them' (McNeill, 2006b) children present with a certain amount of resilience, thus strengths, it is argued, are an important aspect and could be important for obstacles to be overcome (Beyond Youth Custody, 2014; Maruna and LeBel, 2009).

Within the paradigm, providing opportunities for children to have their needs met is promoted alongside being respectful and anti-discriminatory. The development of a strong caring relationship between the worker and the service user is deemed important and in turn is emphasised in the desistence paradigm (McNeill, et al., 2005).

\section{Conclusion: Beyond What Works?}

The idea that 'nothing' can be done to reduce offending is often associated with the work of Robert Martinson (1974). He argued that the poor design quality of the many programmes evaluated, prevented the identification of positive outcomes (McGuire and Priestly, 1995). However, as a result of the 'what works' movement, it has been shown that programmes that are well structured, multi-dimensional and consist of a cognitive behavioural element are most effective at reducing crime (Lipsey, 1995; Utting and Vennard, 2000).

However, although the principles for effective practice have been identified, there has been concern that the set of principles have been uncritically accepted by professionals, whereby certain programmes (or forms of intervention) are deemed to be the 'royal path to success' (Nacro, 2006:6). Indeed, Pitts (2001) has argued that the 'what works' movement has led to a form of 'zombification' whereby practitioners are denied discretion, and more specifically the ability to be creative when working with individual young people. Despite this, the ability to empathise with the child using effective forms of communication - demonstrating 'warmth' and 'genuineness' for example - is deemed to be important to practitioners, alongside 'the ability ... to recognise and acknowledge the 'reality' of the 'lived experiences' of young people' (Prior and Mason: 2010:215). Indeed, intervention should be informed by the need to enhance the personal and social skills of young people, after all 'social circumstances and relationships with others are both the object of the intervention and the medium through which change can be achieved' (Farrall, 2002:21). However, before considering how to respond to a child's offending, one should begin to ask the young person specifically what they think about crime and anti-social 
behaviour, and gather personal viewpoints on 'alternatives' to offending (Barry, 2009).

It is very often adults who collect and interpret the evidence, and decide 'what works' with offenders (Hine, 2010). However, insights provided by children can enhance understanding of 'what works', particularly when trying to understand how 'effective' an intervention is - either at reducing crime or addressing welfare needs (Beyond Youth Custody, 2014).

\section{References}

Baker, K., Kelly, G. and Wilkinson, B. (2011) Assessment in youth Justice. Bristol: The Policy Press.

Barry, M. (2009) 'Promoting desistance amongst young people' in Taylor, T., Earle, R. and R. Hester, R. (eds.) (2009) Youth Justice Handbook: Theory, Policy and Practice. Cullompton: Willan Publishing.

Batchelor, S. and McNeill, F. (2005) 'The Young Person-Worker Relationship', in T. Bateman and J. Pitts (eds) The RHP Companion to Youth Justice. Lyme Regis: Russell House Publishing. pp. 166-71.

Bateman, T. and Pitts, J. (2005) The RHP Companion to Youth Justice. Lyme Regis: Russell House.

Beyond Youth Custody, (2014) Young people and resettlement: Participatory approaches a practitioner's guide, available at:

http://www.beyondyouthcustody.net/wp-content/uploads/Participatoryapproaches-for-young-people-in-resettlement-a-practitioner\%E2\%80\%99squide.pdf (accessed 16/05/2014).

Bhui, H. (2001), "New probation: closer to the end of social work?", British Journal of Social Work, Vol. 31 No. 4, pp. 637-9.

Burnett R and McNeill F (2005) The place of the officer- offender relationship in assisting offenders to desist from crime, Probation Journal, 52(3), 247-68.

Burnett R. (2004) One-to-one ways of promoting desistance: in search of an evidence base. In: Burnett R and Roberts C (eds) What Works in Probation and Youth Justice: Developing Evidence-based Practice. Cullompton : Willan Publishing.

Creaney, S. and Smith, R. (2014) "Youth justice back at the crossroads" Safer Communities, Vol. 13 No. 2, pp. 83-87.

Farrall, S. (2002), Rethinking What Works with Offenders: Probation, Social Context and Desistance from Crime. Cullompton: Willan Publishing. 
Hill M (1999) What's the problem? Who can help? The perspectives of children and young people on their well-being and on helping professionals. Journal of Social Work Practice 13(2): 135-45.

Hine, J. (2010) 'Young people's 'voices' as evidence', in Taylor, W. Earl, R. and Hester, R. (eds) Youth Justice Handbook: theory, policy and practice. Cullompton: Willan Publishing.

King, S. (2013) 'Early desistance narratives: A qualitative analysis of probationers' transitions towards desistance' Punishment and Society 15 (2): 147-165.

Koprowska, J. (2010) Communication and Interpersonal Skills in Social Work, 3rd edn. Exeter: Learning Matters.

Lipsey, M.W. (1995) What do we learn from 400 research studies on the effectiveness of treatment with juvenile delinquents? In What Works? Reducing Reoffending, edited by J. McGuire. New York, NY: John Wiley, pp. 63-78.

Mair, G. (1997).“Community Penalties and Probation”, In M. Maguire, R. Morgan and R. Reiner (eds.) The Oxford Handbook of Criminology (2nd edition), Oxford: Clarendon Press, pp. 123-45.

Martinson, R. (1979) New findings, new views: A note of caution regarding sentencing reform, Hofstra Law Review, 7, 243-258.

Martinson, R. (1974) What Works? Questions and answers about prison reform. The Public Interest, 10, 22-54.

Maruna S and LeBel T (2009) Strengths-based approaches to reentry: Extra mileage toward reintegration and destigmatization, Japanese Journal of Sociological Criminology, 34, 58-80.

McGuire, J. and Priestley, P. (1995) 'Reviewing 'what works': past, present and future in McGuire, J. (ed.) What Works: Reducing Reoffending - Guidelines from Research and Practice. Chichester: John Wiley \& Sons.

McGuire J., Kinderman P., and Hughes C. ( 2002) Offending Behaviour Programmes. London : Youth Justice Board.

McNeill, F. and Batchelor, S. (2002) 'Chaos, Containment and Change: Responding to Persistent Offending by Young People', Youth Justice, Vol. 2, No. 1, pp. 27-43.

McNeill, F., Batchelor, S., Burnett, R. \& Knox, J. (2005). Reducing re-offending: Key practice skills. Edinburgh: Scottish Executive.

McNeill F (2006a) Community supervision: Context and relationships matter. In: Goldson B and Muncie J (eds) Youth Crime and Justice. London: SAGE. 
McNeill F (2006b) A desistance paradigm for offender management, Criminology and Criminal Justice, 6(1), 39-62

Mclvor, G. (1990) 'Community service and custody in Scotland', The Howard Journal 29: $101-13$.

Nacro, (2006) Youth crime briefing: effective practice with children and young people who offend - part 1. London: Nacro.

Nacro, (2007) Youth crime briefing: effective practice with children and young people who offend - part 2. London: Nacro.

National Youth Agency (2011a) Participation in Youth Justice: Measuring Impact and Effectiveness, Leicester: National Youth Agency.

Nugent, B. and Barnes, P (2013) 'desistance and young people' Scottish Justice Matters [online] available at: http://scottishjusticematters.com/wpcontent/uploads/SJM 1-2 December2013 DesistanceAndYoungPeopleLo-Res.pdf accessed: 01/04/2014.

Pitts, J (2001) 'Korrectional Karaoke: New Labour and the zombification of youth justice', Youth Justice, Vol 1, Number 2.

Prior D and Mason P (2010) 'A different kind of evidence? Looking for what works in engaging young offenders' Youth Justice 10(3) pp.211-226.

Raynor, Peter (2004) 'Rehabilitative and Reintegrative Approaches', in A. Bottoms, S. Rex and G. Robinson (eds) Alternatives to Prison: Options for an Insecure Society, pp. 195-223. Cullompton: Willan.

Rex, S (1999) 'Desistance from Offending: Experiences of Probation', Howard Journal of Criminal Justice, 36(4): 366-383.

Robinson, G. and Crow, I. (2009). Offender Rehabilitation: Theory, Research and Practice. London, UK: Sage.

Smith, D. (2006) 'Youth Crime and Justice: Research, Evaluation and Evidence', in B. Goldson and J. Muncie (eds) Youth Crime and Justice. London: Sage.

Trevithick, P. (2012) Social Work Skills and Knowledge: A Practice Handbook, 3rd edn. Open University Press.

Trevithick, P. (2005a) Social Work Skills: A Practice Handbook, 2nd edn, Maidenhead, Open University Press.

Utting, D and Vennard, J (2000) What works with young offenders in the community? London: Barnardos 
Weaver B and McNeill F (2007) Giving up crime: Directions for policy, Scottish Consortium on Crime and Criminal Justice: Edinburgh

Weaver B and McNeill F (2010) Travelling hopefully: Desistance research and probation practice, in Brayford J, Cowe $\mathrm{F}$ and Deering $\mathrm{J}$ (eds), What else works? Creative work with offenders, Willan: Cullompton

Whyte, B. (2004) 'Effectiveness, Research and Youth Justice', Youth Justice 4(1): 321.

Whyte, B. (2009) Youth Justice in Practice: Making a Difference, Bristol: The Policy Press. 